\title{
MENGAPA PERUSAHAAN MEMBAYAR DIVIDEN?
}

\author{
Novi S. Budiarso \\ (Email : novi_sbudiarso@yahoo.com)
}

\begin{abstract}
Dividend decisions, as determined by a firm's dividend policy, are a type of financing decisions that affects the amount of earnings that a firm distributes to shareholders versus the amount of retains and reinvests. This paper examine the determinats of dividend payout of firms listed on Indonesian stock exchanges. Different variables related to the firms operations; profitability, firm size, leverage and liquidity was analyzed on the dividend payouts of the firm.

Using of 230 sample firms over the period 2010 to 2011, this study try to explore the dividend policy. Regression logistic binary was applied to analysis the research questions.

Results Show that profitability, and firm size have significant relationship with the dividend payout of the company, while leverage and liquidity have insignificant relationship with dividend payout. This indicate that in Indonesian stock exchange firm pay dividend based on their profit, the larger the firm the willing the firm to pay dividend.
\end{abstract}

Keywords : Profitability, Firm Size, Leverage, Liquidity, Dividend Payout

\section{PENDAHULUAN}

Dividen telah menjadi tajuk utama dalam penelitian-penelitian keuangan dan menimbulkan masalah kontroversi dalam manajemen keuangan. Kebijakan dividen dari perusahaan merupakan teka-teki untuk peneliti keuangan dan menjadi suatu hal yang penting karena dua alasan: disatu pihak itu adalah faktor yang berpengaruh pada investasi perusahaan dan dapat mengurangi sumber daya internal dan meningkatkan kebutuhan untuk sumber daya eksternal keuangan, di sisi lain, sebagian besar pemegang saham menginginkan kebijakan dividen tunai. Karena itu, untuk memaksimalkan kesejahteraan pemegang saham, manajer harus membuat keseimbangan antara kepentingan yang berbeda dari pemegang saham dan peluang yang menguntungkan untuk investasi.

Kebijakan dividen memberikan kesempatan untuk melakukan penelitian tentang bagaimana perusahaan mengelola secara bersamaan bersaing kepentingan pemegang saham dan kreditur. Dividen mengurangi kekhawatiran pemegang saham tentang pengambilalihan oleh para manajer, dilain pihak mengintensifkan kekhawatiran kreditur tentang pengambilalihan atas pemegang saham. Kebijakan dividen dari waktu ke waktu selalu menjadi teka-teki bagi peneliti. Manajer mempertahankan keuntungan perusahaan untuk berinvestasi kembali dan mengurangi pembiayaan untuk mendapatkan peluang investasi ke tingkat yang wajar atau menyatakan bagian dari itu sebagai dividen dan bahwa keuntungan yang didistribusikan sesuatu yang akan mengurangi sumber daya yang tersedia untuk investasi. Dividen merupakan laba perusahaan yang dibagikan perusahaan kepada shareholders. Ada banyak alasan mengapa perusahaan memilih untuk membayar dividen atau tidak. Beberapa perusahaan memilih untuk mengubah laba menjadi dividen namun ada juga perusahaan yang memilih untuk melakukan investasi dari laba yang diperoleh. Motivasi aktual perusahaan membayar dividen belum jelas. 
Penelitian ini bertujuan untuk menemukan faktor-faktor finansial yang mempengaruhi dividen pada perusahaan yang terdaftar pada Bursa Efek Indonesia (BEI). Selanjutnya apakah terdapat hubungan antara karakteristik finansial yang berbeda sehubungan dengan perusahaan membayar dividen atau tidak? Faktor-faktor apa yang mempengaruhi strategi pembayaran dividen? Penelitian ini juga berusaha mengeksplorasi teori mana dari kebijakan dividen yang menjelaskan perilaku dividen tersebut.

\section{TINJAUAN PUSTAKA}

Dividend Irrelevance Theory dari Miller dan Modigliani (1961) menyatakan bahwa nilai perusahaan dan kemakmuran dari shareholder tidak beruhubungan dengan keputusan harus membayar dividen atau tidak. Shareholders bisa mengadakan sendiri "homemade", jika perusahaan tidak membayar dividen maka shareholders bisa menjual saham dan membuat dividen homemade. Brigham dan Houston (2004) menyatakan bahwa jika perusahaan membayar dividen yang tinggi maka shareholders akan memilih untuk menggunakan kelebihan dividen untuk membeli saham tambahan. Kedua argument ini yang menggarisbawahi asumsi dari irrelevance hypothesis, dimana argumen ini menyatakan bahwa tidak ada perbedaan antara capital gains dan dividen. Hal ini yang membuat shareholders tidak menginginkan untuk membayar harga yang tinggi untuk saham dengan dividen yang tinggi.

Penelitian-penelitian selanjutnya menyatakan bahwa Dividend Irrelevance Theory tidak didasarkan pada pasar modal yang sempurna. Hasil penelitian empiris yang berbeda menyajikan bukti bahwa keputusan dividen relevan dengan nilai dan kemakmuran dari shareholders. Salah satu asumsi adalah Bird In Hand Theory oleh Lintner (1956) yang menyatakan bahwa dividen secara positif memiliki hubungan dengan nilai perusahaan. Investor memberikan nilai lebih tinggi atas dividend yield dibandingkan dengan capital gain yang diharapkan dari pertumbuhan harga saham apabila perusahaan menahan laba untuk dipakai membelanjai investasi, karena komponen dividend yield risikonya lebih kecil dibandingkan dengan komponen pertumbuhan pada persamaan pendapatan yang diharapkan. Argumen ini didasarkan pada ketidakpastian yang tinggi sehubungan dengan capital gains dan dividen yang dibayar pada masa yang akan datang. Dividen yang dibayarkan saat ini lebih bisa diprediksi dari pada capital gains, sejak harga saham ditentukan oleh pasar dan bukan oleh manajer, hal ini yang membuat tingginya tingkat ketidakpastian. Meskipun demikian, Gordon (1962) mengatakan bahwa didasarkan atas pemikiran logis bahwa nilai waktu yang semakin jauh, semakin tinggi tingkat ketidakpastian sehubungan dengan capital gains dan dividen. Capital gains di masa depan bisa menyajikan return yang tinggi lebih dari pembayaran dividen saat ini, tidak ada jaminan bahwa investor akan mengakumulasi return yang tinggi sehubungan dengan tingkat ketidakpastian yang tinggi.

Signaling Theory merupakan salah satu teori yang menyatakan adanya hubungan antara dividen dengan harga saham. Bhattacharya (1979) mengatakan bahwa dividen berfungsi sebagai signal terhadap arus kas masa depan. Meskipun tidak ada manfaat pajak atas dividen, perusahaan akan memilih untuk membayar dividen dengan tujuan memberikan signal positif kepada shareholders dan outside shareholders. Bhattacharya mengasumsikan bahwa investor memiliki informasi yang sempurna sehubungan dengan dividen dan capital gains, serta pajak atas dividen lebih tinggi dibandingkan dengan capital gains. Baker (2009) mengatakan bahwa sumber informasi perusahaan seperti data akuntansi dan laporan prospek masa depan tidak sepenuhnya dapat diandalkan karena belum menggambarkan profitabilitas perusahaan di masa yang akan datang. Oleh karena investor memiliki informasi yang tidak sempurna sehubungan dengan laba perusahaan maka perusahaan harus mencari cara lain untuk meyakinkan investor luar tentang 
arus kas dan laba masa yang akan datang. Peningkatan pembayaran dividen merupakan salah satu signal kepada investor, meskipun dividen dikenakan pajak yang lebih tinggi dibandingkan dengan capital gains, investor mau membayar pajak yang tinggi atas dividen untuk menukarnya dengan signal positif dari dividen sehubungan dengan nilai dari saham.

Teori lainnya adalah Agency Theory. Rozeff (1982) menguji hubungan antara pembayaran dividen dan beberapa faktor perusahaan. Hasil penelitian menyatakan adanya hubungan antara jumlah shareholders dengan pembayaran dividen. Menurut Rozeff perusahaan dengan kepemilikan shareholders eksternal yang besar harus membayar dividen yang tinggi untuk mengurangi konflik keagenan. Hasil ini menunjukkan bahwa terdapat hubungan yang negatif antara pembayaran dividen dengan risiko, kepemilikan insider dan pertumbuhan. Sedangkan antara pembayaran dividen kepemilikan insider memiliki hubungan yang negatif, karena dengan adanya kepemilikan saham yang besar oleh insiders maka perusahaan tidak harus membayar dividen yang tinggi. Selain itu Rozeff mengatakan bahwa kemungkinan pertumbuhan dimasa depan memiliki dampak terhadap dividen dibandingkan dengan pertumbuhan masa lalu yang telah direalisasi. Menurut Jensen dan Meckling (1976), biaya keagenan merupakan biaya yang timbul antara principals (stockholders) dan agents (management). Dimana principals mempekerjakan dan mendelegasikan agent dengan tujuan memaksimalkan kesejahteraan principals. Hanya saham dan utang yang bisa digunakan sebagai klaim terhadap perusahaan. Namun Jensen dan Meckling tidak menyajikan bukti yang kuat sehubungan dengan efek dari biaya keagenan terhadap kebijakan dividen. Easterbrook (1984) melakukan pengujian apakah pembayaran dividen bisa digunakan untuk meminimalkan biaya keagenan yang terjadi antara manajer dan investor. Ada dua faktor yang mempengaruhi biaya keagenan suatu perusahaan, biaya monitoring dan risk aversion preferences dari manajer.

Teori lain yang menjelaskan biaya keagenan adalah free cash flow oleh Jensen (1986), biaya keagenan timbul seiring kenaikan free cash flow. Karena shareholders harus melakukan supervisi guna mencegah manajer dari usaha memperbesar pengeluaran dan investasi yang tidak menguntungkan. Hal yang sama dinyatakan oleh Agrawal dan Jayaraman (1994), ratio pembayaran dividen oleh equity firms lebih tinggi dari levered firms yang merupakan kelompok kontrol. Selanjutnya equity firms, dengan kepemilikan manajerial yang rendah melakukan pembayaran dividen yang tinggi. Secara keseluruhan dividen dan kepemilikan manajerial merupakan mekanisme substitusi guna mengurangi biaya keagenan pada equity firms.

Life cycle theory menyatakan bahwa kebijakan dividen yang optimal dari perusahaan tergantung pada tingkat siklus hidup perusahaan. Semakin dewasa perusahaan semakin meningkat rasio pembayaran dividen yang optimal. Pembayar dividen adalah perusahaan dewasa, dengan rasio yang tinggi dari laba untuk kontribusi modal, sedangkan perusahaan baru, pertumbuhan yang tinggi tidak membayar dividen.

Penelitian tentang hubungan antara dividen dan profitabilitas dilakukan oleh Pruitt dan Gitman (1991), Fama dan French (2000), Al-Kuwari (2009), Al- Malkawi, Twairesh dan Harery (2013) hasil penelitian menyatakan bahwa profitabilitas memiliki hubungan signifikan dengan pembayaran dividen. Ukuran perusahaan merupakan salah satu faktor yang menentukan pembayaran dividen. Penelitian tentang hubungan antara ukuran perusahaan dan pembayaran dividen dilakukan oleh Redding (1997), Al-Kuwari (2009), Shubiri (2011) dan Mehta (2012). Hubungan antara Leverage dan pembayaran dividen dilakukan oleh Gupta dan Banga (2010), hasil penelitian mengatakan bahwa leverage memiliki hubungan signifikan negative dengan pembayaran dividen, perusahaan akan membayar dividen jika memanfaat laba ditahan (risiko rendah) dibandingkan dengan dana eksternal ekuitas dan utang. Dengan kata lain tingkat 
pembayaran yang tinggi akan mengakibatkan pembayaran dividen yang rendah. Alam dan Hossain (2012) dalam penelitiannya menyatakan bahwa leverage memiliki hubungan yang signifikan dengan pembayaran dividen. Penelitian tentang hubungan antara likuiditas dan pembayaran dividen dilakukan oleh Zameer, Rasool, Iqbal dan Arshad (2013) yang menyatakan bahwa terdapat hubungan negatif signifikan antara likuiditas dengan pembayaran dividen. Sedangkan penelitian Maniagi, Ondiek, Musiega, Maokomba dan Egessa (2013) menyatakan bahwa likuiditas tidak berpengaruh signifikan terhadap pembayaran dividen.

\section{METODE PENELITIAN}

\subsection{Jenis dan Sumber Data}

Jenis data dalam penelitian ini adalah data kuantitatif yang berupa data rasio keuangan yang berasal dari laporan keuangan audit dan terpublikasi untuk periode tahun 2010 sampai dengan tahun 2011. Sedangkan sumber data dalam penelitian ini adalah berasal dari Bursa Efek Indonesia (BEI).

\subsection{Populasi dan Sampel}

\begin{tabular}{lr}
\hline \multicolumn{1}{c}{ Sektor } & Jumlah \\
\hline Agriculture & 25 \\
Mining & 58 \\
Basic Industry And Chemicals & 112 \\
MiscellaneousIndustry & 77 \\
Trade, Services \& Investment & 182 \\
\hline \multicolumn{1}{c}{ Total } & $\mathbf{4 5 4}$ \\
\hline
\end{tabular}

Populasi dalam penelitian ini adalah seluruh perusahaan perbankan yang terdaftar pada Bursa Efek Indonesia yang berjumlah 502 perusahaan. Sample penelitian dipilih menggunakan metode purposive sampling, diperoleh 227 perusahaan sebagai sample penelitian dengan 454 observasi.

\subsection{Metode Analisis}

Metode analisis yang digunakan dalam penelitian ini adalah uji regresi logistic binary. Model yang digunakan pada regresi logistik multinomial adalah:

$$
D_{\text {dummy }}=\beta_{0}+\beta D E R+\beta R O A+\beta S i z e+\beta C R+c
$$

\subsubsection{Penilaian Kesesuaian Model (model fit test)}

Terdapat 3 (tiga) cara penilaian kesesuaian model regresi logistik dengan data yang ada. Ketiga cara tersebut menurut Ghozali (2009) yaitu dengan melihat penurunan nilai statistik -2 Log Likelihood, kenaikan nilai $\mathrm{R}^{2}$ Cox dan Snell/nilai $\mathrm{R}^{2}$ Nagelkerke, dan nilai probabilitas dari statistik Hosmer-Lemeshow.

Nilai -2 Log Likelihood Ratio dengan melihat penurunan nilai statistik -2 Log Likelihood. Penurunan nilai -2 Log Likelihood yang dimaksudkan adalah penurunan nilai sebelum dan setelah adanya variabel bebas dalam model. Selanjutnya selisih nilai -2 Log Likehood ini dibandingkan dengan nilai $\chi^{2}$. Tabel dengan selisih derajat kebebasan/degree of freedom (df). Derajat kebebasan yang dimaksudkan yaitu derajat kebebasan setelah penambahan variabel bebas $(\mathrm{df} 2)^{7}$ dan derajat kebebasan sebelum adanya penambahan variabel bebas $(\mathrm{df} 1)^{8}$. 
Apabila nilai selisih statistik $-2 \log$ Likelihood lebih besar daripada $\chi^{2}$ tabel, maka dapat dikatakan penurunan nilai statistik -2 Log Likehood signifikan, artinya penambahan variabel bebas ke dalam model memperbaiki kesesuaian model, Ghozali (2009).

Koefisien Cox dan Snell Square dan Nagelkerke R Square Cox dan Snell's R Square merupakan ukuran yang hampir sama dengan $\mathrm{R}^{2}$ pada multiple regression yang didasarkan pada estimasi likelihood dengan nilai maksimum kurang dari 1 (satu) sehingga sulit diinterpretasikan. Negelkerke's $R^{2}$ merupakan modifikasi dari koefisien Cox dan Snell untuk memastikan bahwa nilainya bervariasi dari 0 (nol) sampai 1 (satu). Hal ini dilakukan dengan cara membagi nilai Cox dan Snell R dengan nilai maksimumnya, Ghozali (2009).

Hosmer dan Lemeshow's Goodness of Fit Tests, keputusan penolakan atau penerimaan hipotesis dilakukan dengan menggunakan tingkat signifikansi 5\%. Hosmer and Lemeshow's Goodness of Fit Tests menguji hipotesis nol bahwa data empiris cocok atau sesuai dengan model (tidak ada perbedaan antara model dengan data sehingga model dapat dikatakan fit. Jika nilai Hosmer and Lemeshow's sama dengan atau kurang dari 0,05 maka hipotesis nol ditolak, berarti ada perbedaan signifikan antara model dengan nilai observasinya sehingga Goodness Fit Model tidak baik, karena model tidak dapat memprediksi nilai observasinya. Jika nilai Hosmer and Lemeshow's lebih besar dari 0,05, maka hipotesis nol diterima, berarti model mampu memprediksi nilai observasinya atau dapat dikatakan model dapat diterima karena cocok dengan data observasinya.

\subsection{Definisi Operasional dan Pengukuran Variabel}

Variabel dependen pada penelitian ini adalah pembayar dividen yang diukur dengan dummy yang memiliki klasifikasi sebagai berikut:

1.Perusahaan yang tidak membayar dividen atau D0

2.Perusahaan yang membayar dividen atau D1

Sedangkan variabel independen yang digunakan dalam penelitian ini adalah profitabilitas, ukuran perusahaan, kepemilikan institusional dan kepemilikan manajerial.

1. Leverage adalah hubungan antara utang perusahaan terhadap modal maupun aset dan untuk menilai seberapa jauh perusahaan dibiayai oleh utang atau pihak luar dengan kemampuan perusahaan yang digambarkan oleh modal (equity) perusahaan yang baik memiliki komposisi modal lebih besar dari utang. Leverage dalam penelitian ini diproksikan dengan Debt to Equity Ratio yaitu, rasio yang menunjukan persentase penyedian dana oleh pemegang saham terhadap pemberi pinjaman yang diformulasikan:

\section{Debt to Equity Ratio $=\frac{\text { Total Liabilities }}{\text { Total Equity }}$}

2. Profitabilitas merupakan kemampuan perusahaan memperoleh laba dalam hubungan dengan penjualan, total aktiva maupun modal sendiri. Profitabilitas diukur dengan menggunakan Return On Assets, yang diformulasikan:

$$
\text { Return On Asset }=\quad \frac{\text { Earnings After Tax }}{\text { Total Asset }}
$$


3. Firm Size (Ukuran perusahaan) adalah besarnya perusahaan menurut total aktiva yang dimiliki, diukur dengan menggunakan $\ln$ total aset.

4. Current Ratio adalah rasio keuangan yang menunjukkan kemampuan perusahaan untuk memenuhi kewajiban-kewajiban jangka pendeknya yang harus dipenuhi. Dalam menganalisis posisi likuiditas perusahaan dapat menggunakan dua macam rasio yaitu :

$$
\text { Current Ratio }=\quad \frac{\text { Current Assets }}{\text { Current Liabilities }}
$$

\subsection{Hipotesis}

Hipotesis penelitian ini disusun sebagai berikut:

Ha1 : Leverage berpengaruh signifikan terhadap kebijakan dividen

Ha2 : Profitabilitas berpengaruh signifikan terhadap kebijakan dividen

Ha3 : Ukuran perusahaan berpengaruh signifikan terhadap kebijakan dividen

Ha4 : Current Ratio berpengaruh signifikan terhadap kebijakan dividen

\section{HASIL DAN PEMBAHASAN}

\subsection{Hasil}

\subsubsection{Analisis Deskriptif}

Statistik deskriptif memberikan gambaran mengenai variabel-variabel dalam penelitian yang dilihat dari nilai rata-rata (mean), standar deviasi, nilai maksimum, dan nilai minimum. Hasil analisis statistik deskriptif dari masing-masing variabel dalam penelitian menggunakan program SPSS (Lihat Tabel 2)

Tabel 2. Statistik Deskriptif

\begin{tabular}{llllll}
\hline & N & Minimum & Maximum & \multicolumn{1}{c}{ Mean } & $\begin{array}{c}\text { Std. } \\
\text { Deviation }\end{array}$ \\
\hline Dividen & 454 & 0.00 & 1.00 & 0.1476 & 0.35507 \\
DER & 454 & -51.33 & 60.22 & 1.3988 & 5.63509 \\
ROA & 454 & -132.03 & 341.56 & 7.5283 & 25.55008 \\
Size & 454 & 8.00 & 19.00 & 13.8150 & 1.93404 \\
CR & 454 & 0.00 & 9007.51 & 317.0050 & 871.34854 \\
Valid N (listwise) & 454 & & & & \\
\hline
\end{tabular}

Jumlah pengamatan dalam penelitian ini sebanyak 454 pengamatan (lihat Tabel 2). Dividen yang merupakan variabel dependen memiliki nilai minimum 0,00 , nilai maksimum 1,00 , rata-rata 0.1476 dan standar deviasi 0.35507 . nilai dari variabel dependen yang berkisar antara 0,00 dan 1,00 karena variabel ini merupakan variable dummy. Leverage yang diukur dengan DER memiliki nilai minimum -51.33 , nilai maksimum 60.22, rata-rata 1.3988 dan standar deviasi 5.63509. Profitabilitas yang diukur dengan ROA memiliki nilai minimum --132.03, nilai maksimum 341.56, rata-rata 7.5283 dan standar deviasi 25.55008. Size atau ukuran perusahaan memiliki nilai minimum 8,00, nilai maksimum 19.00, rata-rata 13.8150, standar deviasi 1.93404 . 
Current Ratio memiliki nilai minimum 0, nilai maksimum 9007.51, rata-rata 317.0050 dan standar deviasi 871.34854.

4.1.2.Penilaian Kesesuaian Model (model fit test)

4.1.2.1.Uji -2 Log Likelihood

Tabel 3. -2 Log Likelihood Step

\begin{tabular}{ccccc}
\hline \multicolumn{1}{c}{ Iteration } & \multicolumn{2}{c}{ Coefficients } \\
\hline & & \multicolumn{2}{c}{-2 Log likelihood } & Constant \\
\cline { 2 - 4 } Step 0 & 1 & 387.304 & -1.410 & \\
& 2 & 380.054 & -1.718 & \\
& 3 & 379.983 & -1.753 & \\
& 4 & 379.983 & -1.754 & \\
Step 1 & 1 & 353.745 & -4.378 & \\
& 2 & 327.813 & -7.709 & \\
3 & 324.788 & -9.360 & \\
4 & 324.718 & -9.631 & \\
5 & 324.718 & -9.638 & \\
6 & 324.718 & -9.638 & \\
\hline
\end{tabular}

Untuk melihat model yang lebih baik untuk memprediksi kemungkinan perusahaan dalam membayar dividen, dilihat dari -2 Log Likelihood. Dari hasil perhitungan -2 Log Likelihood step 0, sebesar 387.304 (lihat Tabel 3). Kemudian terjadi penurunan pada step 1 nilai -2 Log Likelihood menjadi 324.718. Dapat disimpulkan bahwa penambahan variable DER, ROA, Size, dan Current Ratio ke dalam model, memperbaiki model fit regresi logistik.

Tabel 4. Omnibus Tests of Model Coefficients

\begin{tabular}{llccr}
\hline \multirow{2}{*}{ Step 1} & Step & Chi-square & df & \multicolumn{1}{c}{ Sig. } \\
\cline { 2 - 5 } & Block & 55.265 & 4 & 0.000 \\
& Model & 55.265 & 4 & 0.000 \\
& 55.265 & 4 & 0.000 \\
\hline
\end{tabular}

Hasil uji Omnibus Tests of Model Coefficients (lihat Tabel 4), merupakan uji simultan dengan tujuan untuk mengetahui apakah DER, ROA, Size, dan Current Ratio, secara bersama sama mempengaruhi kebijakan dividen. Dari data tabel 4 dapat diketahui bahwa selisih -2 Log Likelihood untuk model yang memasukkan konstanta saja dengan -2 Log L untuk model dengan konstanta dan variabel bebas adalah 55.265 dengan signifikansi 0,000. Nilai signifikansi yang lebih kecil dari 0,05 menunjukkan bahwa hipotesis nol ditolak, dan penambahan variabel bebas ke dalam model memperbaiki model fit. 
4.1.2.2. Hosmer and Lemeshow's Goodness of Fit Test

Tabel 5. Hosmer and Lemeshow's Goodness of Fit Test

\begin{tabular}{cccc} 
Step & Chi-square & df & Sig. \\
\hline 1 & 9.626 & 8 & 0.292 \\
\hline
\end{tabular}

Hasil pengujian (lihat Tabel 5) menunjukkan Chi-square sebesar 18.756 dengan nilai probabilitas signifikan sebesar $0.292>0,05$ maka hipotesis nol diterima. Hal ini berarti model regresi layak untuk digunakan dalam analisis selanjutnya, karena tidak ada perbedaan yang nyata antara klasifikasi yang diprediksi dengan klasifikasi yang diamati. Atau dapat dikatakan bahwa model mampu memprediksi nilai observasinya.

\subsubsection{Uji Nagelkerke's $R$ Square}

Tabel 6. Hasil Pengujian Nagelkerke's R Square Model Summary

\begin{tabular}{|c|c|c|}
\hline -2 Log likelihood & $\begin{array}{c}\text { Cox \& Snell R } \\
\text { Square }\end{array}$ & $\begin{array}{c}\text { Nagelkerke } R \\
\text { Square }\end{array}$ \\
\hline $324.718^{\mathrm{a}}$ & 0.115 & 0.202 \\
\hline $\begin{array}{l}\text { Nilai Nagelkerke's } \mathrm{R} \text { Square (lih } \\
\text { variabilitas variabel dependen yang dap } \\
\text { sebesar } 20.2 \% \text {, sisanya sebesar } 79.8 \% \text { dijelas } \\
\text { model penelitian. Atau secara bersama-sama } \\
\text { dapat menielaskan variasi variabel Pembavar }\end{array}$ & $\begin{array}{l}\text { Tabel 6) adalah sebesar } \\
\text { dijelaskan oleh variabel } \\
\text { oleh variabilitas variabel } \\
\text { asi variabel DER, ROA, } S \\
\text { Sividen sebesar } 20.2 \% \text {. }\end{array}$ & $\begin{array}{l}0.202 \text { yang berarti } \\
\text { independen adalah } \\
\text { - variabel lain di luar } \\
\text { ize, dan Current Ratio }\end{array}$ \\
\hline
\end{tabular}

\subsubsection{Ketepatan Prediksi Klasifikasi}

\section{Tabel 7. Klasifikasi}

\begin{tabular}{|c|c|c|c|c|}
\hline & & \multicolumn{3}{|c|}{ Predicted } \\
\hline & & $D_{d u n}$ & & Percentage \\
\hline \multicolumn{2}{|c|}{ Observed } & $\begin{array}{l}\text { Tidak membayar } \\
\text { dividen }\end{array}$ & $\begin{array}{l}\text { Membayar } \\
\text { dividen }\end{array}$ & \\
\hline \multirow[t]{3}{*}{ Step 1} & Dividen Tidak membayar dividen & 384 & 3 & 100.0 \\
\hline & Membayar dividen & 63 & 4 & 0.0 \\
\hline & Overall Percentage & & & 85.5 \\
\hline
\end{tabular}

Output tabel klasifikasi (lihat Tabel 7) mengindikasikan dalam model regresi logistik, perusahaan yang tidak membayar dividen adalah 387 perusahaan sedangkan hasil observasi menunjukkan hanya 384 perusahaan, jadi ketepatan klasifikasi yang diamati untuk perusahaan yang tidak membayar dividen sebesar 0.99\% (384/387). Sedangkan prediksi untuk perusahaan yang membayar dividen 67 perusahaan, sedangkan hasil observasi menunjukkan hanya 63 perusahaa, maka ketepatan prediksi klasifikasi yang diamati untuk perusahaan yang membayar dividen $0.06 \%$ (4/67). Secara keseluruhan ketepatan klasifikasi prediksi sebesar $85.5 \%$ 


\subsection{Pembahasan}

Tabel 8. Variables in the Equation

95\% C.I.for

$\operatorname{EXP}(\mathrm{B})$

\begin{tabular}{|c|c|c|c|c|c|c|c|c|c|}
\hline \multirow{6}{*}{ Step $1^{\mathrm{a}}$} & & B & S.E. & Wald & $d f$ & Sig. & $\operatorname{Exp}(B)$ & Lower & Upper \\
\hline & ROA & 0.017 & 0.005 & 11.841 & 1 & 0.001 & 1.017 & 1.007 & 1.027 \\
\hline & DER & -0.036 & 0.037 & 0.950 & 1 & 0.330 & 0.964 & 0.896 & 1.038 \\
\hline & Size & 0.536 & 0.087 & 38.172 & 1 & 0.000 & 1.710 & 1.442 & 2.027 \\
\hline & CR & 0.000 & 0.000 & 0.010 & 1 & 0.920 & 1.000 & 0.999 & 1.001 \\
\hline & Constant & -9.638 & 1.326 & 52.801 & 1 & 0.000 & 0.000 & & \\
\hline
\end{tabular}

a. Variable(s) entered on step 1: Size, ROA, SC

Output variables in the equation (lihat Tabel 8) menunjukkan nilai signifikansi berdasarkan Wald Statistic, jika model signifikan, maka nilai sig. adalah kurang dari 0,05. Hasil perhitungan dari Wald Statistic menunjukkan bahwa variabel ROA dan Size berpengaruh signifikan terhadap variable pembayaran dividen, sedangkan variable DER dan CR tidak berpengaruh signifikan terhadap variable pembayaran dividen.

a.Hasil uji Hipotesis $\mathrm{Ha}_{1}$

Koefisien variabel ROA: uji Wald $=11.841$, signifikan pada probabilitas $0.001<\alpha=0.05$. Arah positif menunjukkan bahwa semakin tinggi ROA maka akan menaikkan kemungkinan pembayaran dividen. Hal ini menunjukkan $\mathrm{Ha}_{1}$ diterima.

Hasil penelitian ini sesuai dengan teori yang mengatakan bahwa bila terjadi kenaikan ROA maka Dividend Payout Ratio akan semakin tinggi. ROA yang tinggi menunjukan kemampuan perusahaan untuk membayar dividen tinggi. Tanda positif dalam penelitian ini sesuai dengan teori Information Content atau Signaling Hypothesis, Modigliani dan Miller (1961) yang menyatakan bahwa kenaikan dividen merupakan suatu sinyal kepada investor bahwa manajemen meramalkan suatu penghasilan yang baik di masa yang akan datang, berdasarkan teori tersebut menunjukkan bahwa penghasilan yang tinggi melalui asset yang dimiliki yang tercermin dalam Return On Asset (ROA) menunjukkan pengaruh positif terhadap kebijakan dividen yang tercermin dalam Dividend Payout Ratio (DPR). Sedangkan La Porta, Lopez, Shleifer dan Vishny (2000) menyatakan bahwa shareholders akan mengambil kas dividen dari laba perusahaan. Penelitian ini mendukung penelitian dari Jensen, Solberg dan Zorn (1992), Han dan Suk (1999) dan Fama dan French (2000).

b. Hasil uji Hipotesis $\mathrm{Ha}_{2}$

Koefisien variable DER: uji Wald $=0.950$, signifikansi pada probabilitas $0.330>\alpha=$ 0.05. Hal ini menunjukkan $\mathrm{Ha}_{2}$ ditolak. Artinya variable DER tidak berpengaruh signifikan terhadap pembayaran dividen.

Hasil penelitian ini bertentangan dengan penelitian Gupta dan Banga (2010) dan Al Makawai (2007) yang mengatakan bahwa leverage memiliki hubungan negative signifikan dengan pembayaran dividen. Hasil penelitian ini juga tidak konsisten dengan penelitian Alam dan Hossain (2010)

b. Hasil uji Hipotesis Ha3

Variabel Size: uji Wald $=38.172$, signifikan pada probabilitas $0.000<\alpha=0.05$. Arah positif menunjukkan bahwa semakin besar ukuran perusahaan maka akan menaikkan kemungkinan pembayaran dividen. Hal ini menunjukkan hipotesis $\mathrm{Ha}_{2}$ diterima. 
Hasil penelitian ini mendukung Agency Costs Theory yang menyatakan bahwa bagi perusahaan besar yng memiliki sebaran kepemilikan yang luas, memiliki kesepakatan kontrol yang baik dimana implikasinya adalah berkurangnya Agency Cost. Lloyd, Jahera dan Page (1995) dan Holder, Langrehr dan Hexter (1998) mengatakan bahwa suatu perusahaan yang sudah mapan akan memiliki akses yang mudah menuju pasar modal untuk meningkatkan dana dengan biaya yang lebih rendah, sementara perusahaan yang baru dan yang masih kecil akan mengalami banyak kesulitan untuk memiliki akses ke pasar modal. Hal ini menyebabkan perusahaan besar cenderung memberikan dividen yang lebih besar disbandingkan perusahaan kecil, karena perusahaan kecil memiliki kecenderungan lebih sedikit dalam mengahasilkan laba, Fama dan French (1995). Penelitian ini mendukung penelitian dari Redding (1997) dan Al-Makawi (2007)

c. Hasil uji Hipotesis $\mathrm{Ha}_{4}$

Variabel Current Ratio: uji Wald 0.010, signifikansi pada probabilitas $0.920>\alpha=0.05$ menunjukkan tidak adanya pengaruh yang signifikan dari variable Current Ratio terhadap pembayaran dividen. Hal ini menunjukkan hipotesis $\mathrm{Ha}_{4}$ ditolak.

Hasil penelitian ini bertentangan dengan penelitian Gupta dan Banga (2010) dan Zameer, Rasool, Iqbal dan Arshad (2013) namun sejalan dengan penelitian Maniagi, Ondiek, Musiega, Maokomba dan Egessa (2013).

Persamaan regresi yang dibentuk adalah:

\section{$D_{\text {dummy }}=-9.638+0.017$ ROA $+-0.036 \mathrm{DER}+0.536 \mathrm{Size}+0.000 \mathrm{CR}+\mathrm{c}$}

\section{Kesimpulan}

Penelitian ini menyimpulkan bahwa profitabilitas, ukuran perusahaan berpengaruh signifikan terhadap pembayaran dividen.Sedangkan leverage dan likuiditas tidak berpengaruh signifikan terhadap pembayaran dividen.

Sehubungan dengan profitabilitas, dapat diinterpretasikan bahwa perusahaan-perusahaan yang terdaftar pada BEI sebagian besar mendasarkan pembayaran dividennya pada profitabilitas perusahaan. Hasil penelitian ini membuktikan adanya berlakunya signaling theory pada perusahaan yang terdaftar di BEI. Ukuran perusahaan dapat menjelaskan keputusan perusahaan dalam pengambilan keputusan apakah akan membayar dividen atau tidak. Semakin besar ukuran perusahaan maka semakin besar probabilitas perusahaan membayar dividen. Leverage tidak berpengaruh signifikan terhadap pembayaran dividen hal ini tidak sejalan dengan Jensen (1986) yang menyatakan bahwa pembayaran dividen merupakan substitusi yang sangat efektif untuk mengurangi biaya agency atas free cash flow karena, relatif terhadap pembayaran dividen. Artinya hasil penelitian ini tidak mendukung teori agency sebagai dasar pembayaran dividen. Hubungan ukuran perusahaan dengan dividen sebagaimana yang dikatakan Fama and French (2001) bahwa dividen cenderung dibayar oleh perusahaan yang besar dengan tingkat profitabilitas yang tinggi dan kesempatan pertumbuhan yang kecil. Hal ini mendukung life cycle theory. Current ratio

\section{Saran}

Penelitian selanjutnya sebaiknya menggunakan sampel yang lebih besar sehingga meningkatkan validitas data. Sampel sebaiknya membandingkan antar sector dari perusahaanperusahaan yang terdaftar di BEI, misalnya antara sektor industri dasar dan kimia dengan sektor keuangan. Analisis ini dapat mengidentifikasikan sector mana yang paling rendah dan tinggi 
dalam hal pembayaran dividen. Untuk pengembangan penelitian selanjutnya, sebaiknya melakukan penambahan variabel yang bisa menjelaskan tentang keputusan perusahaan untuk membayar dividen atau tidak, misalnya pertumbuhan perusahaan, likuiditas, laba dan lain-lain.

\section{DAFTAR PUSTAKA}

Alam, MD, Zahangir dan Hossain, M. E. (2012). Dividend Policy: A Comparative Study of UK and Bangladesh Based Companies. IOSR Journal of Business and Management, 1(1), 5767.

Brigham, E. F dan Houston, J. F. (2004). Fundamentals of Financial Management. 10 edition Mason: South-Western

Fama, E. F. dan French K. R. (2001). Disappearing dividends: changing firm characteristics or lower propensity to pay? Journal of Financial Economics 60, 3-43

Ghozali, Imam. (2009). Aplikasi Analisis Multivariate dengan Program SPSS. Badan Penerbit Universitas Diponegoro. Semarang.

Gugler, K. (2003). Corporate governance, dividend payout policy, and the interrelation between dividends, R\&D, and capital investment. Journal of Banking and finance, 27, 1297-1321.

Gupta, A., and Banga, C. (2010). The Determinants Of Dividend Policy. Indian Institute of Management Calcutta. Decision 37(2), 63-77.

Han, K., S. Lee, dan Suk, D. (1999). Institutional Shareholders and Dividends. Journal of Financial and Strategic Decisions, Spring 12, 53-62.

Holder, M. E., Langrehr, F. W., dan Hexter, L. J. (1998). Dividend policy determinants: an investigation of the influences of stakeholder theory. Journal of the Financial Management, 27 (3), 73-83.

Jensen, M. C. (1986). Agency Cost of Free Cash Flow, Corporate Finance and Takeovers. The American Economic Review, 76 (2), 323-329.

Jensen, G., D. Solberg dan Zorn, T. (1992), Simultaneous Determination of Insider Ownership, Debt, and Dividend Policies. Journal of Financial and Quantitative Analysis 27, 274-263.

Kuwari-Al, D. (2009). Determinants of the Dividend Policy in Emerging Stock Exchange: the Case of GCC Countries. Global Economy \& Finance Journal. 2(2) September 2009, 3863

La Porta, R., F. Lopez-De-Silanes, Shleifer, A dan Vishny, R. (2000), Agency Problems and Dividend Policy around the World. Journal of Finance, 55(1), 1-33.

Lintner, J. (1956). Distribution of Incomes of Corporations Among Dividends, Retained Earnings, and Taxes. The American Economic Review, 46(2), 97-113.

Lloyd, W.P., Jahera J. S., dan Page, D. E. (1985). Quarterly Journal of Business and Economics. 24(3). Summer, 19-29

Mehta, A. (2012). An Empirical Analysis of Determinants of Dividend Policy -Evidence from the UAE Companies. Global Review of Accounting and Finance. 3(1). March 2012, 18 31

Miller, M. H. dan Modigliani, F. (1961). Dividend Policy, Growth, and the Valuation of Shares. Journal of Business 34, 411-433

Maniagi, G. M., B. A.,Ondiek, Musiega, D., Maokomba, O. C., dan Egessa, R. (2013). Determinants Of Dividend Payout Policy Among Non-Financial Firms On Nairobi 
Securities Exchange, Kenya. International Journal Of Scientific \& Technology Research,2(10), 253-266.

Rozeff , M. S. (1982). Growth, Beta and Agency Costs as Determinants of Dividend Payout Ratios. Journal of Financial Research, 5(3), 249-259.

Short, H., H. Zhang dan Keasey, K. (2001), The Link between Dividend Policy and Institutional Ownership. Journal of Corporate Finance, 8, 105-122.

Shubiri-Al, F. N. (2011). Determinants of Changes Dividend Behavior Policy: Evidence from the Amman Stock Exchange. Far East Journal of Psychology and Business, 4 (2), 1-15 